\title{
Noah Revisits Biodiversity Prioritization
}

\author{
David W. Martin \\ Departments of Economics and Environmental Studies, Davidson College, Davidson, USA \\ Email: damartin@davidson.edu
}

How to cite this paper: Martin, D.W. (2016) Noah Revisits Biodiversity Prioritization. Modern Economy, 7, 1272-1289. http://dx.doi.org/10.4236/me.2016.711122

Received: September 1, 2016

Accepted: October 8, 2016

Published: October 11, 2016

Copyright (@) 2016 by author and Scientific Research Publishing Inc. This work is licensed under the Creative Commons Attribution International License (CC BY 4.0).

http://creativecommons.org/licenses/by/4.0/ (c) (i) Open Access

\begin{abstract}
The challenge of using limited funds to protect biodiversity has motivated much important research. One important line of work has been based upon the Noah's Ark metaphor developed by Weitzman (1998). I summarize the main criticisms of that model and use those to develop heuristically a new variation of that model. That new policy ranking model includes ecological value and diversity as well as the economic benefits and costs and probability of successful protection that Weitzman used. I demonstrate the model with an example of two policies intended to enhance Keoladeo National Park in India, and conclude by discussing how the example highlights the importance of the interactions of all five of those aspects.
\end{abstract}

\section{Keywords}

Biodiversity, Noah's Ark, Natural Capital, Conservation

\section{Introduction}

A wide variety of analyses demonstrate that biodiversity is currently declining and will continue to decline through this century [1], and a recent study [2] concluded that biodiversity intactness has fallen below boundary thresholds in many terrestrial biomes and terrestrial biodiversity hot spots. Although both developed and developing countries have agreed to increase dramatically their funding for biodiversity protection by over $\$ 10$ billion annually [3], that financial support is far less than the $\$ 76$ billion annually that McCarthy et al. [4] concluded was necessary. That is also far less than the $\$ 93.3$ billion (in 1990 dollars) annual cost of moving 10\% of the world's forest and agricultural lands into ecological preserves, a likely target for protecting biodiversity [5]. I address the policy challenge of picking the right quantity of the right components of biodiversity to save with limited funding.

The understanding that valuing various bits of biodiversity is a complex endeavor is not new, even for economists. One hundred years ago Gray [6] identified one of the 
core issues in conservation economics as: "What is the criterion of social value?" Van der Ploeg, Braat, and Van Lierop [7] framed the relevant question as: how do and how well do economic models and ecological models integrate the other's perspective of value and methodologies? A little bit later in a lecture reviewing the role of economics in protecting biodiversity, Gowdy [8] emphasized: "To formulate policies to protect biodiversity, it is critical to broaden the standard economic view to include environment-economy interconnections, irreversibility, and the environmental context of specific resources." At about the same time in a review of economic models for the American Society of Zoologists, Norgaard [9] noted: "the process of [biodiversity] loss is intimately related to human beliefs that the world is a very simple system which people can control, is very resilient to human interaction, and has infinite potential for human exploitation through new knowledge and technologies." So, economists have not been shy in recognizing the importance of trying to integrate economic and ecological concerns.

But it is not clear that economists have been successful in this effort. At first blush, the fact that Bartkowski et al.'s [10] analysis of the biodiversity valuation literature yielded a sample of 123 studies that empirically valued biodiversity implies that economists have been making progress. Yet, Farnsworth et al. [11] concluded that only 9 of those studies valued biodiversity as scientists define it rather than valuing the naturalness of the ecosystem or some component of the ecosystem. While both Bartkowski et al. [10] and Farnsworth et al. [11] might disagree with how Waldron et al. [12] defined how underfunded countries' biodiversity protection measures might be, both sets of analysts would agree that improving such measures would allow the limited biodiversity protection funding to be directed most efficiently.

Consistent with that motivation, I develop a model that follows from Weitzman's [13] Noah's Ark perspective of this policy challenge. Derived from the Abrahamic religious traditions (Torah Book of Bereshit, Bible Book of Genesis, and Qur'an Surah 11), the metaphor follows from the belief that God destroyed the world by flooding it with the exception of the people, animals, and plants Noah saved in the Ark. Weitzman [13] first has Noah calculating the ratio of incremental benefits to incremental costs for species and then loading the ark such that the species that enters next has the highest ratio of benefits to costs. Although the ark is filled before all possible species can enter, due to the point that the ecological and economic benefits of biodiversity jointly increase with diminishing returns [14] this procedure ensures that Noah saves only the most valuable species. In a pragmatic variant of this exercise, Fuller et al. [15] determined that Australian conservation efforts could be improved per dollar spent by selling the lands with low ratios of benefits to costs and using (only) those funds to buy unprotected areas with higher ratios of benefits to costs. Similarly, Banks-Leite et al. [16] demonstrate a cost-effective strategy for identifying the appropriate amount of land set-asides in the Brazilian Atlantic Forest. So, even if there literally is no Noah identifying which species to save there is a general recognition of the value of maximizing the benefits from the spending of limited protection funds. 
I begin by summarizing the main criticisms of that model, and then I use those critiques to develop heuristically a new variation of that model. That new policy ranking model includes ecological value and diversity as well as the economic benefits and costs and probability of successful protection that Weitzman used. I demonstrate the model with an example of two policies intended to enhance Keoladeo National Park in India, and conclude by discussing how the example highlights the importance of the interactions of all five of those aspects.

\section{Initial Discussion of the Noah's Ark Model}

Equation (1) below represents Weitzman's [13] ranking $\left(R_{i}\right)$ of species $i$ in terms of the value per cost of saving that species $\left(C_{i}\right)$. The term $\Delta P_{i}$ represents the change in the probability of the survival of that species as a result of the policy. Its inclusion allows for trade-offs between the benefits of a policy and the likelihood of the policy being successful [17], which Weitzman [18] demonstrates with an intriguing pedagogical example involving the crane family (Gruiformes gruidae). $U_{i}$ represents the utility gained from the species, which is a measure the use value of the species. $D_{i}$ represents the genetic distinctiveness of the species, a measure intended to capture the option value (the benefits that might flow from the species in the future).

$$
R_{i}=\left[U_{i}+D_{i}\right] \frac{\Delta P_{i}}{C_{i}}
$$

$\Delta P_{i}$ is small enough that it does not affect the probabilities of the survival of other species [13]. As (for example) Wardle et al. [19] stress, biodiversity changes are not just about the loss of a single species; they lead to complex ecological changes that in turn drive gains for some species and losses for others. Thus, this convenient assumption builds into the model vulnerability to the criticism that economists tend to represent very poorly the important ecological themes of complexity, interrelatedness, feedbacks, and irreversibility [20] [21]. But, this particular simplification is not the only common one.

Another simplification is the use only of use and option values to assess the economic value of a species when broader measures are available. For example, Krutilla [22] emphasized that the irreproducibility of natural phenomena and the irreversibility of the decisions that affect ecosystems will create nonuse values. Also, it is important to include social, cultural, and religious values (e.g., Thompson and Starzomski [23], Bryan et al. [24], Rutte [25], and Daniel et al. [26]) and the value of ecosystems services (e.g., Kareiva et al. [27] and Atkinson, Bateman, and Mourato [28] (2012)). It seems clear that the better choice for economic value is total economic value [29], as that does not arbitrarily limit the analysis to a select set of value sources.

A different common simplification is to replace both numerator terms in Equation (1) - the measure of economic value and the change in the probability-with a single measure of ecological value. This step is intended to incorporate a measure of biodiversity value independent of its value to humans as well as to implicitly assume that the protection policies will be successful. Generally speaking (see the review of nine of these 
strategies by Brooks et al. [30]), these "hot spot" analyses identify ecologically rich areas and then allocate funding for preservation efforts in a manner that minimizes diversity losses per dollar spent. For example, Dinerstein and Wikramanayake [31] conducted an analysis for the Indo-Pacific region, Myers et al.'s [32] identified international ecological hotspots, and Withey et al. [33] ranked all of the counties in the conterminous U.S. by their conservation potential.

In another variant, Perry [34] replaced $\left[U_{i}+D_{i}\right]$ in Equation (1) with ecological importance, leaving the probability term in the equation. He used Equation (2) below as an example measure of the ecological importance of a species $\left(M_{i}\right)$. It increases as the number of species in the $i^{\text {th }}$ species function group $\left(F_{i}\right)$ decreases and as the number of species affected by the $i^{\text {th }}$ species' function $\left(N_{i}\right)$ increases.

$$
M_{i}=\frac{\sqrt{N_{i}}}{F_{i}}
$$

Farnsworth et al. [35] propose an alternative ecological valuation methodology, one based on ecological complexity. To measure that concept, they proposed to examine how a food web's ecosystem functions (e.g., biomass and inter-trophic energy flows) are reduced when a species is removed from the web. Owen [36] proposes another ecological measure, a measure of species uniqueness that is not conceptually dissimilar from Weitzman's [13] [17] [18] genetic distinctiveness. All three of these measures of ecological value are consistent with the point that several important studies have featured benefit measures other than the anthropomorphic measures economists use.

A more crucial simplification explicit in the Noah's Ark model to this point arises from the abstraction away from the concept of diversity. Consider E.O. Wilson's [37] popular definition of biodiversity: "[A]ll hereditarily based variation at all levels of organization, from the genes within a single local population or species, to the species composing all or part of a local community, and finally to the communities themselves that compose the living parts of the multifarious ecosystems of the world." Expanding upon that definition Naeem, Duffy, and Zavaleta [38] describe seven different relevant forms of such variation: taxonomic diversity, phylogentic diversity, genetic diversity, functional diversity, spatial or temporal diversity, interaction diversity, and landscape diversity.

A common measure of variation as the basis for biodiversity builds upon Hill's [39] definition of gamma diversity (overall diversity) as:

$$
{ }_{\gamma}^{q} D=\left(\sum_{i=1}^{s} f_{i}^{q}\right)^{\frac{1}{1-q}},
$$

where the $I=1$ to $S$ species have relative abundance equal to $f_{i}$. There is no special significance to the choice of $q$, but three values are linked to different commonly used diversity indices ( $q=0$ to species richness, $q=1$ to the Shannon index, and $q=2$ to the Simpson index). Although gamma diversity can be partitioned into alpha diversity (within-location diversity) and beta diversity (between-location diversity) (see, e.g. [40]-[42]), Socolar et al. [43] summarize the challenges with using beta diversity as a 
guide for species protection policy. As a simple example, consider the loss of an apex predator with a range that extends across several locations. The dynamics related to that loss could affect the alpha and beta diversities across all of those locations in a variety of ways. There might even be repercussions across other locations to that extent that species affected by the introduction have ranges outside the range of the introduced apex predator. While other diversity measures have been proposed (e.g., zeta diversity [44]), it makes the most sense to stick with a standard diversity measure [45].

\section{Heuristic Development of a Broader Model for Noah}

Implicit in the discussions reviewed in the previous section is the common theme for analysts to focus on only one aspect or a very limited number of aspects when analyzing biodiversity policy. Analysts often (a) focus on species' economic or (b) ecological values or (c) work with diversity measures and (d) they may or may not consider the costs of the policy and (e) they may or may not consider the probability of policy success. To Weitzman's [13] credit, he rigorously developed the Noah's Ark model to consider three of those five aspects. The key goal in this section is to build upon that strong framework and add the missing components.

It can be seen in the previous paragraph that there are two bifurcations within analytical styles. One bifurcation is at the choice of using valuation or diversity measures and the second occurs at the choice of using economic valuation or ecological valuation. To the extent that double or triple counting can be avoided, these two binary decisions are rather arbitrary when one can simply multiply the relevant values [46]. This process allows a large change in one factor to offset a small change in other factors. That is the basis for the product of value and probability in the numerator of the original Equation (1).

The figurative starting point for this metaphor is to ask, what is Noah viewing as potentially entering that Ark? In a more realistic world, Noah is not looking at individual species but is instead looking at individual policies with the likelihood that each policy will affect many species and locations. So, in what follows, the subscript $i$ will index the $1, \ldots, N$ different biodiversity policies that Noah must consider and the ranking will be assessed upon the changes due each policy. This change is more important than a subtle notation shift as it allows for the consideration of the interactions between species across various habitats that ecologists have been encouraging.

Another notational consideration is that all of the valuation measures described below will be in present value terms even though the notation is not explicit in that point. This consideration is consistent with the over 100 years of the economic practice of factoring temporal dynamics into resource conservation analysis [6] as well as being consistent with the ecological perspective [47] [48]. Finally, given his divine guidance, Noah is able to optimize across all possible orderings of policy implementation so as to load the correct sequence of policies into the Ark. The analysis of the optimal present value methodology and sequencing algorithms are left for other forums.

Equation (4) below gives the ranking $\left(R_{i}\right)$ of policy $i$ in terms of its marginal value and likely success $\left(P_{i}\right)$ relative to its cost $\left(C_{i}\right)$. It builds upon Weitzman's [13] original 
suggestion although economic value is assessed with economic value $\left(\triangle T E V_{i}\right)$ and it adds ecological value $\left(\Delta M_{i}\right)$ and gamma (overall) diversity $\left(\Delta_{\gamma}^{q} D_{i}\right)$.

$$
R_{i}=\left(\Delta T E V_{i}\right)\left(\Delta M_{i}\right)\left(\Delta_{\gamma}^{q} D_{i}\right) \frac{P_{i}}{C_{i}}
$$

While this straight-forward extension is a response to several important criticisms of Weitzman's [13] model, it does not address all of Mainwaring's [49] criticisms. One of Mainwaring's [49] concerns was that this approach is rarely possible as the data are rarely available. Consequently, in the next section I develop an example to demonstrate that the approach is useful, both in terms of guiding policy makers and in terms of highlighting the research needs that would improve policy decisions.

\section{Example}

Consider two different policies intended to enhance the bird population at Keoladeo National Park (KNP) in Rajasthan, India. The first policy is to allow the water of the Gambhir River to flow freely instead of being impounded for irrigation purposes by the Panchana Dam; Frank [50] summarizes the issues related to this impoundment. For this example, assume that the status quo imperils half of the $9.6 \mathrm{~km}^{2}$ of wetlands $(4.8$ hectares) in KNP [51]. The second policy is to compensate farmers near KNP for voluntarily maintaining satellite wetlands on their property. About $42.5 \mathrm{~km}^{2}$ of satellite wetlands appear to be usable as agricultural fields [52]. To be consistent with the other policy, assume that compensating farmers will prevent the conversion of half of those wetlands (2120 hectares).

The first policy is intended to help the revival of the Siberian Crane (Grus leucogeranus) in KNP. The potentially extinct central Siberian Crane population nested in western Siberia and wintered in India, particularly at KNP because it requires wetlands apart from humans for nesting, feeding, and roosting [53]. The successful reintroduction of the Whooping Crane [54] suggests that it might be possible to reintroduce the Siberian Crane to this flyway. The largest Siberian Crane population in KNP was 41 [51], so assume that the population would increase to 10 cranes from zero. Because it does not alter the proximity of farmers to their lands, the policy of compensating farmers to maintain the satellite wetlands will not improve the viability of the Siberian Crane.

The second policy is intended primarily to benefit the Indian Sarus Crane (Grus Antigone). In contrast to the Siberian Crane, the Sarus Crane tends to be non-migratory in India and it utilizes human-dominated wetlands; as will be noted later the farmers in this region do not grow rice, so the crane's use of rice paddies is irrelevant here [55]. Lacking information about the number of Sarus Cranes, assume that the increase in them due to protecting the Gambhir River flow will be four times the increase in Siberian Cranes (so to 40) and that the same number (40) will not be lost if the satellite wetlands are protected.

To broaden this example beyond those two cranes, the impact of those policies upon the Greater Spotted Eagle (Clanga clanga) will be examined (and by implication the 
impacts upon other species will be ignored for the sake of simplicity). This migratory eagle breeds in northern Europe and western Asia, and it winters in India where it relies upon a mosaic of lowland forests near wetlands with a minimum of permanent human presence [56]. There were 6 Greater Spotted Eagles in KNP in 2004-2005 [52]. Assume that the status quo's combination of lost wetlands in KNP and lost satellite wetlands would lead the total disappearance of this eagle from this area, and by restoring the Gambhir's flow half of those eagles (3) could be saved and protecting the satellite wetlands would also save half ( 3 ) of them.

The total annual economic value of the policies will be simplified to represent three components: the direct gain in consumer surplus for the tourists, the indirect benefits gained the local community, and the gain in wetland services. The omission of existence value is discussed in the concluding section. Chopra [57] estimated that there is a consumer surplus gain of $\$ 5$ per (Indian and foreigner) visitor to KNP and Chopra and Adhikari [58] estimated that there is a minimum indirect income gain to the community of 12 times the gate fees collected. Recently there were 45,000 foreign tourists who paid gate fees of $\$ 4$ and 55,000 Indian tourists who paid gate fees of $\$ 1$ [59]. Russi et al. [60] estimate that each hectare of inland wetland annually provides $\$ 1000$ of ecosystem services. The changes in total economic value for the two policies are presented in $\mathrm{Ta}$ ble 1.

Table 1. Summary of policies' rankings.

\begin{tabular}{|c|c|c|}
\hline & Restoring Gambhir River Flow & $\begin{array}{c}\text { Paying Farmers to } \\
\text { Protect Satellite Wetlands }\end{array}$ \\
\hline $\begin{aligned} \Delta T E V_{i}= & \Delta \text { Direct }_{i}+\Delta \text { Indirect }_{i} \\
& +\Delta \text { cosystem }_{i}\end{aligned}$ & $\begin{array}{l}{[(\$ 5)(100,000)]} \\
+[(\$ 48)(45,000)+(\$ 12)(55,000)] \\
+[(\$ 1,000)(480)] \\
=\$ 500,000+\$ 2,820,000+\$ 480,000 \\
=\$ 3,800,000\end{array}$ & $\begin{array}{l}{[(\$ 0)(100,000)]} \\
+[(\$ 0)(45,000)+(\$ 0)(55,000)] \\
+[(\$ 1,000)(2,120)] \\
=\$ 0+\$ 0+\$ 2,120,000 \\
=\$ 2,120,000\end{array}$ \\
\hline$\Delta M_{i}=\sum_{\substack{\text { Affeced } \\
\text { Species }}}\left(\Delta \frac{\sqrt{N_{j}}}{F_{j}}\right)$ & $\begin{array}{l}\left(\frac{\sqrt{409}}{3}-\frac{\sqrt{407}}{2}\right) \\
+\left(\frac{\sqrt{409}}{1}-\frac{\sqrt{407}}{1}\right) \\
+\left(\frac{\sqrt{409}}{1}-0\right) \\
=-3.3+0.0+20.2 \\
=16.9\end{array}$ & $\begin{array}{l}\left(\frac{\sqrt{408}}{2}-\frac{\sqrt{407}}{2}\right) \\
+\left(\frac{\sqrt{408}}{1}-\frac{\sqrt{407}}{1}\right) \\
+\left(\frac{\sqrt{408}}{1}-0\right) \\
=0.0+0.0+20.2 \\
=20.2\end{array}$ \\
\hline$\Delta_{\gamma}^{0} D_{i}$ & 2.0 & 1.0 \\
\hline$P_{i}$ & 0.1 & 0.4 \\
\hline$C_{i}$ & $\$ 7,400,000$ & $\$ 1,100,000$ \\
\hline$R_{i}=\left(\Delta T E V_{i}\right)\left(\Delta M_{i}\right)\left(\Delta_{\gamma}^{q} D_{i}\right) \frac{P_{i}}{C_{i}}$ & $\begin{array}{l}\left(\frac{128648124}{7400000}\right)(0.1) \\
=(17.4)(0.1)=1.7\end{array}$ & $\begin{array}{l}\left(\frac{42900666}{1100000}\right)(0.4) \\
=(39.0)(0.4)=15.6\end{array}$ \\
\hline
\end{tabular}


For simplicity in this example, consider Perry's [34] definition of ecological importance (Equation (2)) using the number of birds in KNP as $N_{i}$. Under the status quo, and so assuming no Siberian Cranes or Greater Spotted Eagles, there would be 407 birds identified with KNP [61]. The policy of restoring the Gambhir River's flow would increase the total number of birds from 407 to 409 while the policy of protecting the satellite wetlands would increase the number to 408. Two of the birds identified with KNP are migratory cranes (Grus grus and Anthropoides virgo) that would be in the same function group as the Siberian Crane; as the only resident crane the Sarus Crane would be the only resident member of its function group; and the Greater Spotted Eagle is the only migratory member of the spotted eagle genus in KNP (Clanga hastata is resident) [61]. So, restoring the Gambhir River's flow would increase the number of members of the Siberian Crane's function group, not affect the Sarus Crane's function group members, and create a function group for the Greater Spotted Eagle. Protecting the satellite wetlands would not affect either Crane's function group but would create one for the Greater Spotted Eagle.

Setting the parameter $q$ to zero for gamma (overall) diversity is attractive for the purposes of this example as ${ }_{\gamma}^{0} D_{i}$ equals the number of species in the habitat [39]. Restoring the Gambhir River's flow would allow for the reintroduction of the Siberian Crane and the protection of the Greater Spotted Eagle, so relative to the status quo gamma diversity increases by 2 . Protecting the satellite wetlands would protect only protect the Greater Spotted Eagle, so the gamma diversity increases by 1 relative to the status quo.

For the sake of calculation, the probabilities of the policies being successful are assigned rather arbitrarily. In particular, the probability of the policy of successfully implementing a program of paying farmers not to convert wetlands seems more likely to succeed than the probability of successfully undoing a program in which politicians chose to build the Panchana Dam and impound the Gambhir River's water. Further, if the goal of the program is to encourage the re-introduction of the Siberian Crane as the motivations have been described here, then the success of that aspect depends upon successfully preventing the hunting of the cranes along the flyway in between Siberia and India. This policy does not address the measures necessary to ensure that protection. So, the probability of success for restoring the Gambhir River's flow was assigned to be 0.1 and then the probability of success for protecting the satellite wetlands was chosen to be four times as likely (0.4). As is evident in Table 1 , for these probabilities to affect the relative ranking of these two policies, the likelihood of successfully restoring the Gambhir River's flow would actually have to be greater than the likelihood of successfully protecting the satellite wetlands, a very unlikely outcome given the political situation.

The details and references for the assessment of the policies' costs are in the "Appendix for Example" section. The costs of restoring the Gambhir's River's flow would be the loss of farming profits from the Panchana Dam's command area net any increase in profits for farmers further downstream. Due to their ability to access irrigation water, 
the farmers in the command area appear to have shifted their Rabi (dry season) crops away from wheat, barley, and gram towards the more valuable mustard. They also expanded the area they farmed. The resulting increase in agricultural revenues of $\$ 7.4$ million per year in the command area is a reasonable assessment of the cost of restoring the Gambhir River's flow. The opportunity costs of protecting the satellite wetlands would be reflected in the payment that would have to be made to the relevant farmers, and those payments would reflect the foregone profits from farming the converted lands. To estimate those payments, assuming again that half satellite wetlands would be converted, additionally assuming that all of those lands would be used for Rabi (dry season) crops and half of the converted lands would be used for Kharif (monsoon season) crops), and also assume that the distribution of crops grown would be similar to the crops grown previously. Given those assumptions, the revenues the converted fields could gain would be $\$ 1.1$ million, which reflect the costs.

The assessment of the rankings (Equation (4)) is Table 1. The policy of protecting the satellite wetlands is strongly preferred to the policy of restoring the Gambhir River's flow.

\section{Concluding Discussion}

As economists continually emphasize, policy analysts need to consider the benefits and the costs of policy choices together instead of looking at only one of those two. As illustrated in Table 1, both the increase in Total Economic Value and the product of the changes Total Economic Value, Ecological Value, and Diversity are greater for the policy of restoring the Gambhir River's flow than for the policy of protecting the satellite wetlands. However, given the lower costs of protecting the satellite wetlands, the ratio of benefits to costs for protecting the satellite wetlands is double (39.0 compared to 17.4) the ratio for restoring the Gambhir River's flow. As noted in Section 2 earlier, it is common in "hot spot" type analyses to exclude the policy costs.

The economic benefits predicted from restoring the Gambhir's flow are dominated by the change in indirect economic benefits to the local community. In contrast, the predicted economic benefits from protecting the satellite wetlands are due entirely to the ecosystem services provided by the protected wetlands. The importance of using Total Economic Value as a concept is that it permits such differences to contribute to the assessment.

Mainwaring's [49] critique about data availability is particularly relevant for deliberate omission of existence value from this example. Not only are marginal existence values for species difficult to obtain, those available in the existing literature are problematic when considering their use to other contexts, for example, potentially transferable assessments of annual marginal existence values for the Siberian and Indian Sarus Cranes and for the Greater Spotted Eagle using \$56 for a Whooping Crane and \$39 for a Bald Eagle [62]. But, those values are estimated for U.S. households, so blindly using those values and the number of Indian households would distort the resulting calculations greatly. In this case, the omission of existence values does not signal a failure of 
the methodology, rather it signals a research need.

The choice of zero for $q$ was also motivation by the lack of data. In this case, the relative frequencies of the bird species in KNP are not available, necessitating that particular simplification. However, since gamma diversity is a monotonic function of $q$ [39], this particular assumption should not affect the relative ranking of the policies.

Using Perry's [34] definition of ecological importance (Equation (2)), one can see in Table 1 that protecting the Greater Spotted Eagle adds the more ecological value than adding the Siberian Crane. Adding a species (protecting a species from extirpation) with a unique function group (the Greater Spotted Eagle) adds substantial ecological value by this measure. Reintroducing the Siberian Crane actually detracts from this type of ecological value because it is assumed to redundantly add another member to an existing function group. So, in this case, even though one might argue that a certain species is iconic enough to merit special attention (the Siberian Crane) it might be more ecologically important to save a less notable species (the Greater Spotted Eagle).

Also as noted earlier, it is also common to ignore the probability of policy success, which implicitly assumes that the policy will be successful. In this example, the relative ranking of the two policies is stable as long as the probability of successfully protecting the satellite wetlands is greater than about one-half of the probability of successfully restoring the Gambhir River's flow, a very likely possibility. It is easy to imagine a different scenario in which the probability assessment is crucial.

Weitzman's [13] original development of the Noah's Ark model was noteworthy for its basic model structure and for the critical analyses, supportive and critical, that it engendered. The policy ranking model here, Equation (4), follows directly from it as well as building upon important critiques. One of the key insights one observes from using it is to see that diversity policy analysis is more complicated than any one single aspect. A second key aspect is that research into specific components of that analysis for specific cases, such as existence value and ecological value, will be important for improving the quality of biodiversity protection decisions.

\section{Acknowledgements}

I wrote the first versions of this paper as a Fulbright-Nehru Research Scholar affiliated with the Institute of Economic Growth (University of Delhi). This paper has been improved substantially as a result of the very helpful questions and comments from seminar participants at the Madras School of Economics, the Sálim Ali Centre for Ornithology and Natural History, the United States India Educational Foundation South and Central Asia Conference, the Institute of Economic Growth, the Dhaka School of Economics, the 2013 meeting of the US Society for Ecological Economics, and the 2013 International Congress for Conservation Biology. An earlier iteration of this paper is available as Working Paper \#323 published by the Institute of Economic Growth, and Mr. Surit Das deserves thanks for his help at that stage. None of the people noted above share any responsibility for whatever issues still exist in this version. 


\section{References}

[1] Pereira, H.M., Leadley, P.W., Proença, V., Alkemade, R., Scharlemann, J.P.W., FernandezManjarrés, J.F., et al. (2010) Scenarios for Global Biodiversity in the 21st Century. Science, 330, 1496-1501. http://dx.doi.org/10.1126/science.1196624

[2] Newbold, T., Hudson, L.N., Arnell, A.P., Contu, S., Palma, A.D., Ferrier, S., et al. (2016) Has Land Use Pushed Terrestrial Biodiversity beyond the Planetary Boundary? A Global Assessment. Science, 353, 288-291. http://dx.doi.org/10.1126/science.aaf2201

[3] Secretariat of the Convention on Biodiversity (2012) At United Nations Biodiversity Conference, Countries Agree to Double Resources for Biodiversity Protection by 2015. United Nations Environment Programmè, Hyderabad. http://www.cbd.int/doc/press/2012/pr-2012-10-20-cop-11-en.pdf

[4] McCarthy, D.P., Donald, P.F., Scharlemann, J.P.W., Buchanan, G.M., Balmford, A., Green, J.M.H., et al. (2012) Financial Costs of Meeting Global Biodiversity Conservation Targets: Current Spending and Unmet Needs. Science, 338, 946-949. http://dx.doi.org/10.1126/science.1229803

[5] Lewandrowski, J., Darwin, R.F., Tsigas, M. and Raneses, A. (1999) Estimating Costs of Protecting Global Ecosystem Diversity. Ecological Economics, 29, 111-125. http://dx.doi.org/10.1016/S0921-8009(98)00058-5

[6] Gray, L.C. (1913) The Economic Possibilities of Conservation. The Quarterly Journal of Economics, 27, 497-519. http://dx.doi.org/10.2307/1883375

[7] Van der Ploeg, S.W.F., Braat, L.C. and Van Lierop, W.F.J. (1987) Integration of Resource Economics and Ecology. Ecological Modelling, 38, 171-190. http://dx.doi.org/10.1016/0304-3800(87)90051-2

[8] Gowdy, J.M. (1993) Economic and Biological Aspects of Genetic Diversity. Society \& Natural Resources, 6, 1-16. http://dx.doi.org/10.1080/08941929309380804

[9] Norgaard, R.B. (1994) The Process of Loss-Exploring the Interactions between Economic and Ecological-Systems. American Zoologist, 34, 145-158. http://dx.doi.org/10.1093/icb/34.1.145

[10] Bartkowski, B., Lienhoop, N. and Hansjürgens, B. (2015) Capturing the Complexity of Biodiversity: A Critical Review of Economic Valuation Studies of Biological Diversity. Ecological Economics, 113, 1-14. http://dx.doi.org/10.1016/j.ecolecon.2015.02.023

[11] Farnsworth, K.D., Adenuga, A.H. and de Groot, R.S. (2015) The Complexity of Biodiversity: A Biological Perspective on Economic Valuation. Ecological Economics, 120, 350-354. http://dx.doi.org/10.1016/j.ecolecon.2015.10.003

[12] Waldron, A., Mooers, A.O., Miller, D.C., Nibbelink, N., Redding, D., Kuhn, T.S., et al. (2013) Targeting Global Conservation Funding to Limit Immediate Biodiversity Declines. Proceedings of the National Academy of Sciences of the United States of America, 110, 12144-12148. http://dx.doi.org/10.1073/pnas.1221370110

[13] Weitzman, M.L. (1998) The Noah’s Ark Problem. Econometrica, 66, 1279-1298. http://dx.doi.org/10.2307/2999617

[14] Béné, C. and Doyen, L. (2008) Contribution Values of Biodiversity to Ecosystem Performances: A Viability Perspective. Ecological Economics, 68, 14-23. http://dx.doi.org/10.1016/j.ecolecon.2008.08.015

[15] Fuller, R.A., McDonald-Madden, E., Wilson, K.A., Carwardine, J., Grantham, H.S., Watson, J.E.M., et al. (2010) Replacing Underperforming Protected Areas Achieves Better Conservation Outcomes. Nature, 466, 365-367. http://dx.doi.org/10.1038/nature09180 
[16] Banks-Leite, C., Pardini, R., Tambosi, L.R., Pearse, W.D., Bueno, A.A., Bruscagin, R.T., et al. (2014) Using Ecological Thresholds to Evaluate the Costs and Benefits of Set-Asides in a Biodiversity Hotspot. Science, 345, 1041-1045. http://dx.doi.org/10.1126/science.1255768

[17] Weitzman, M.L. (1992) On Diversity. The Quarterly Journal of Economics, 107, 363-405. http://dx.doi.org/10.2307/2118476

[18] Weitzman, M.L. (1993) What to Preserve? An Application of Diversity Theory to Crane Conservation. The Quarterly Journal of Economics, 108, 157-183. http://dx.doi.org/10.2307/2118499

[19] Wardle, D.A., Bardgett, R.D., Callaway, R.M. and Van der Putten, W.H. (2011) Terrestrial Ecosystem Responses to Species Gains and Losses. Science, 332, 1273-1277. http://dx.doi.org/10.1126/science.1197479

[20] Eppink, F.V. and van den Bergh, J.C.J.M. (2007) Ecological Theories and Indicators in Economic Models of Biodiversity Loss and Conservation: A Critical Review. Ecological Economics, 61, 284-293. http://dx.doi.org/10.1016/j.ecolecon.2006.01.013

[21] Tisdell, C.A. (2011) Core Issues in the Economics of Biodiversity Conservation. Annals of the New York Academy of Sciences, 1219, 99-112. http://dx.doi.org/10.1111/j.1749-6632.2010.05889.x

[22] Krutilla, J.V. (1967) Conservation Reconsidered. The American Economic Review, 57, 777786.

[23] Thompson, R. and Starzomski, B.M. (2007) What Does Biodiversity Actually Do? A Review for Managers and Policy Makers. Biodiversity and Conservation, 16, 1359-1378.

http://dx.doi.org/10.1007/s10531-005-6232-9

[24] Bryan, B.A., Raymond, C.M., Crossman, N.D. and King, D. (2011) Comparing Spatially Explicit Ecological and Social Values for Natural Areas to Identify Effective Conservation Strategies. Conservation Biology, 25, 172-181. http://dx.doi.org/10.1111/j.1523-1739.2010.01560.x

[25] Rutte, C. (2011) The Sacred Commons: Conflicts and Solutions of Resource Management in Sacred Natural Sites. Biological Conservation, 144, 2387-2394. http://dx.doi.org/10.1016/j.biocon.2011.06.017

[26] Daniel, T.C., Muhar, A., Arnberger, A., Aznar, O., Boyd, J.W., Chan, K.M.A., et al. (2012) Contributions of Cultural Services to the Ecosystem Services Agenda. Proceedings of the National Academy of Sciences of the United States of America, 109, 8812-8819. http://dx.doi.org/10.1073/pnas.1114773109

[27] Kareiva, P.M., Tallis, H., Ricketts, T.H., Daily, G.C. and Polasky, S., Eds. (2011) Natural Capital: Theory and Practice of Mapping Ecosystem Services. Oxford University Press, Oxford.

[28] Atkinson, G., Bateman, I. and Mourato, S. (2012) Recent Advances in the Valuation of Ecosystem Services and Biodiversity. Oxford Review of Economic Policy, 28, 22-47. http://dx.doi.org/10.1093/oxrep/grs007

[29] Walsh, R.G., Loomis, J.B. and Gillman, R.A. (1984) Valuing Option, Existence, and Bequest Demands for Wilderness. Land Economics, 60, 14-29. http://dx.doi.org/10.2307/3146089

[30] Brooks, T.M., Mittermeier, R.A., da Fonseca, G.A.B., Gerlach, J., Hoffmann, M., Lamoreux, J.F., et al. (2006) Global Biodiversity Conservation Priorities. Science, 313, 58-61. http://dx.doi.org/10.1126/science.1127609

[31] Dinerstein, E. and Wikramanayake, E.D. (1993) Beyond "Hotspots": How to Prioritize Investments to Conserve Biodiversity in the Indo-Pacific Region. Conservation Biology, 7, 53-65. http://dx.doi.org/10.1046/j.1523-1739.1993.07010053.x 
[32] Myers, N., Mittermeier, R.A., Mittermeier, C.G., da Fonsea, G.A.B. and Kent, J. (2000) Biodiversity Hotspots for Conservation Priorities. Nature, 403, 853-858.

http://dx.doi.org/10.1038/35002501

[33] Withey, J.C., Lawler, J.J., Polasky, S., Plantinga, A.J., Nelson, E.J., Kareiva, P., et al. (2012) Maximising Return on Conservation Investment in the Conterminous USA. Ecology Letters, 15, 1249-1256. http://dx.doi.org/10.1111/j.1461-0248.2012.01847.x

[34] Perry, N. (2010) The Ecological Importance of Species and the Noah's Ark Problem. Ecological Economics, 69, 478-485. http://dx.doi.org/10.1016/j.ecolecon.2009.09.016

[35] Farnsworth, K.D., Lyashevska, O. and Fung, T. (2012) Functional Complexity: The Source of Value in Biodiversity. Ecological Complexity, 11, 46-52. http://dx.doi.org/10.1016/j.ecocom.2012.02.001

[36] Owen, N. (2014) Life on the Edge. Significance, 11, 26-29. http://dx.doi.org/10.1111/j.1740-9713.2014.00780.x

[37] Wilson, E.O. (1996) Introduction. In: Reaka-Kudla, M.L., Wilson, D.E. and Wilson, E.O., Eds., Biodiversity II: Understanding and Protecting Our Biological Resources, John Henry Press, Washington DC, 1-3.

[38] Naeem, S., Duffy, J.E. and Zavaleta, E. (2012) The Functions of Biological Diversity in an Age of Extinction. Science, 336, 1401-1406. http://dx.doi.org/10.1126/science.1215855

[39] Hill, M.O. (1973) Diversity and Evenness: A Unifying Notation and Its Consequences. Ecology, 54, 427-432. http://dx.doi.org/10.2307/1934352

[40] Whittaker, R.H. (1960) Vegetation of the Siskiyou Mountains, Oregon and California. Ecological Monographs, 30, 279-338. http://dx.doi.org/10.2307/1943563

[41] Whittaker, R.H. (1972) Evolution and Measurement of Species Diversity. Taxon, 21, 213251. http://dx.doi.org/10.2307/1218190

[42] MacArthur, R.H. (1965) Patterns of Species Diversity. Biological Reviews of the Cambridge Philosophical Society, 40, 510-533. http://dx.doi.org/10.1111/j.1469-185X.1965.tb00815.x

[43] Socolar, J.B., Gilroy, J.J., Kunin, W.E. and Edwards, D.P. (2016) How Should Beta-Diversity Inform Biodiversity Conservation? Trends in Ecology \& Evolution, 31, 67-80. http://dx.doi.org/10.1016/j.tree.2015.11.005

[44] Hui, C. and McGeoch, M.A. (2014) Zeta Diversity as a Concept and Metric That Unifies Incidence-Based Biodiversity Patterns. The American Naturalist, 184, 684-694. http://dx.doi.org/10.1086/678125

[45] Tuomisto, H. (2010) A Consistent Terminology for Quantifying Species Diversity? Yes, It Does Exist. Oecologia, 164, 853-860. http://dx.doi.org/10.1007/s00442-010-1812-0

[46] Arponen, A. (2012) Prioritizing Species for Conservation Planning. Biodiversity and Conservation, 21, 875-893. http://dx.doi.org/10.1007/s10531-012-0242-1

[47] Duffy, J.E. (2009) Why Biodiversity Is Important to the Functioning of Real-World Ecosystems. Frontiers in Ecology and the Environment, 7, 437-444. http://dx.doi.org/10.1890/070195

[48] Reich, P.B., Tilman, D., Isbell, F., Mueller, K., Hobbie, S.E., Flynn, D.F.B., et al. (2012) Impacts of Biodiversity Loss Escalate Through Time as Redundancy Fades. Science, 336, 589-592. http://dx.doi.org/10.1126/science.1217909

[49] Mainwaring, L. (2001) Biodiversity, Biocomplexity, and the Economics of Genetic Dissimilarity. Land Economics, 77, 79-93. http://dx.doi.org/10.2307/3146982

[50] Frank, A.M. (2011) Keoladeo National Park: Highlighting Surface Water Tensions. Interdisciplinary Environmental Review, 12, 231-243. http://dx.doi.org/10.1504/ier.2011.041820 
[51] United Nations Environment Programme and World Conservation Monitoring Centre (2008) Keoladeo National Park, Rajasthan, India. http://www.unep-wcmc-apps.org/sites/wh/pdf/Keoladeo.pdf

[52] Mathur, V.B., Choudhury, B.C., Sinha, P.R. and Verma, A. (2006) Ecological Monitoring in Keoladeo National Park and Its Environs for Enhancing Management Effectiveness. UNESCO-IUCN. http://whc.unesco.org/uploads/activities/documents/activity-331-17.pdf

[53] International Crane Foundation (2016) Siberian Crane. https://www.savingcranes.org/species-field-guide/siberian-crane/

[54] International Crane Foundation (2016) Whooping Crane. https://www.savingcranes.org/species-field-guide/whooping-crane/

[55] International Crane Foundation (2016) Sarus Crane. https://www.savingcranes.org/species-field-guide/sarus-crane/

[56] BirdLife International (2016) Species Factsheet (Clanga clanga). http://www.birdlife.org/datazone/speciesfactsheet.php?id=3531

[57] Chopra, K. (2004) Economic Valuation of Biodiversity: The Case of Keoladeo National Park. In: Kadekodi, G.K., Ed., Environmental Economics in Practice: Case Studies from India, Oxford University Press, New Delhi, Oxford, and New York, 86-121.

[58] Chopra, K. and Adhikari, S.K. (2004) Environment Development Linkages: Modelling a Wetland System for Ecological and Economic Value. Environment and Development Economics, 9, 19-45. http://dx.doi.org/10.1017/S1355770X03001037

[59] Various Authors (2016) Keoladeo National Park. https://en.wikipedia.org/wiki/Keoladeo_National_Park

[60] Russi, D., ten Brink, P., Farmer, A., Badura, T., Coates, D., Förster, J., et al. (2013) The Economics of Ecosystems and Biodiversity for Water and Wetlands. The Institute for European Environmental Policy and the Ramsar Convention Secretariat, London \& Brussels and Gland.

[61] Lepage, D. (2016) Keoladeo National Park, Bharatpur Bird Checklist. Avibase-Bird Checklists of the World.

http://avibase.bsc-eoc.org/checklist.jsp?region=INnwrj01\&list=howardmoore

[62] Richardson, L. and Loomis, J.B. (2009) The Total Economic Value of Threatened, Endangered and Rare Species: An Updated Meta-Analysis. Ecological Economics, 68, 1535-1548. http://dx.doi.org/10.1016/j.ecolecon.2008.10.016

[63] Office of the Chief Engineer, Irrigation Department (2002) Panchana Irrigation Project, District Karauli (Raj.): Revised Estimate. Government of Rajasthan, Jaipur.

[64] Directorate of Economics and Statistics, Rajasthan (2004) District Statistical Outline, Karauli District, 2003. Jaipur, Rajasthan, India.

[65] Directorate of Economics and Statistics, Rajasthan (2005) District Statistical Outline, Karauli District, 2004. Jaipur, Rajasthan, India.

[66] Directorate of Economics and Statistics, Rajasthan (2007) District Statistical Outline, Karauli District, 2005. Jaipur, Rajasthan, India.

[67] Directorate of Economics and Statistics, Rajasthan (2010) District Statistical Outline, Karauli District, 2006. Jaipur, Rajasthan, India.

[68] Directorate of Economics and Statistics, Rajasthan (2005) District Statistical Outline, Sawai Madhopur District, 2004. Jaipur, Rajasthan, India.

[69] Directorate of Economics and Statistics, Rajasthan (2009) District Statistical Outline, Sawai Madhopur District, 2006. Jaipur, Rajasthan, India. 
[70] Directorate of Economics and Statistics, Rajasthan (2010) District Statistical Outline, Sawai Madhopur District, 2007. Jaipur, Rajasthan, India.

[71] Directorate of Economics and Statistics, Rajasthan (2010) District Statistical Outline, Sawai Madhopur District, 2008. Jaipur, Rajasthan, India.

[72] Directorate of Economics and Statistics, Rajasthan (2011) District Statistical Outline, Sawai Madhopur District, 2009. Jaipur, Rajasthan, India.

[73] Directorate of Economics and Statistics, Department of Agriculture and Cooperation (n.d.) Farm Harvest Prices of Principal Crops in India. http://eands.dacnet.nic.in/FHP(District).htm

[74] Directorate of Economics and Statistics, Department of Agriculture and Cooperation (2013) Farm Harvest Prices of Principal Crops in India. State-Wise (2001-02 to 2003-04), Farm Harvest Prices of Principal Crops in Rajasthan-Districtwise (Rupees per quintal). http://eands.dacnet.nic.in/fhprice/Rajasthan01-04.pdf

[75] Directorate of Economics and Statistics, Department of Agriculture and Cooperation (n.d.) Farm Harvest Prices of Principal Crops in India. State-Wise (2004-05), Farm Harvest Prices of Principal Crops in Rajasthan-Districtwise (Rupees per quintal). http://eands.dacnet.nic.in/FHP_2004-05/Rajasthan.pdf

[76] Directorate of Economics and Statistics, Department of Agriculture and Cooperation (n.d.) Farm Harvest Prices of Principal Crops in India. State-Wise (2005-06), Farm Harvest Prices of Principal Crops in Rajasthan-Districtwise (Rupees per quintal). http://eands.dacnet.nic.in/FHP_2005-06/Rajasthan.pdf

[77] Directorate of Economics and Statistics, Department of Agriculture and Cooperation (n.d.) Farm Harvest Prices of Principal Crops in India. State-Wise (2006-07 to 2007-08), Farm Harvest Prices of Principal Crops in Rajasthan-Districtwise (Rupees per quintal). http://eands.dacnet.nic.in/fhprice/FHP2007-08/Rajasthan.pdf

[78] Directorate of Economics and Statistics, Department of Agriculture and Cooperation (n.d.) Farm Harvest Prices of Principal Crops in India. State-Wise (2008-09 to 2009-10), Farm Harvest Prices of Principal Crops in Rajasthan-Districtwise (Rupees per quintal). http://eands.dacnet.nic.in/fhprice/FHP-2008-2009-2009-10/Rajasthan\%20.pdf

[79] Varshney, V. (2005) Gripe Water: Bird-brained Politics Mars Bharatpur Wetlands. Down to Earth, 13, 7-8.

[80] Directorate of Economics and Statistics, Rajasthan (2011) District Statistical Outline, Bharatpur District, 2008. Jaipur, Rajasthan, India. 


\section{Appendix for the Example}

The basic administrative unit of an Indian state is the district, and the basic administrative unit of a district is the tehsil. Tehsil-level data are available from the state of Rajasthan's Directorate of Economics and Statistics in books titled District Statistical Outline (जिलासांख्यिकीयरूपरेखा). From January through March, 2013, I visited several university and governmental libraries in Jaipur (the capital of Rajasthan) and New Delhi, but was only able to access a couple of copies of the District Statistical Outline. In April 2013, I visited the state office of the Directorate as well as the district-level statistical officers and purchased all of the relevant District Statistical Outlines from 1990 through the present. Thus, the information used for the calculations below is based upon all of the available data.

The information in Tables A1-A4 is based upon the command area for the Panchana Dam, which falls in three tehsils in the district of Karauli and one tehsil in the district of Sawai Modhopur (although it was originally in the district of Karauli) [63]. For Karauli, the data are from the 2003, 2004, 2005, and 2006 District Statistical Outlines [64]-[67]. For Sawai Modhopur, the data are from the 2004, 2006, 2007, 2008, and 2009 District Statistical Outlines [68]-[72]. These tehsil-level data is from the Central Government and include the area planted, the crop output, and the harvest prices, with the exception of the harvest price of mustard [73]. The price of mustard is at the district level and is from the Central government [74]-[78]. The reservoir at Panchana started filling with the rains in the summer of 2004 and was first used for irrigation purposes for the following rabi season [79], which is the 2004-2005 agricultural year.

The information in Tables A5-A7 is based upon the most recent District Statistical Outline for the district of Bharatpur [80], the location of Keoladeo National Park. The

Table A1. Average hectares planted in rabi (dry season) crops.

\begin{tabular}{cccccc}
\hline & Wheat & Barley & Gram & Mustard & All rabi \\
\hline $2001-2002-2003-2004$ & 11,959 & 230 & 2813 & 9107 & 26,704 \\
$2004-2005-2007-2008$ & 10,478 & 122 & 1490 & 23,302 & 35,809 \\
\hline
\end{tabular}

Table A2. Average hectares planted in rabi (dry season) crops.

\begin{tabular}{cccccc}
\hline & Wheat & Barley & Gram & Mustard & Sum \\
\hline $2001-2002-2003-2004$ & $47.1 \%$ & $0.9 \%$ & $9.9 \%$ & $34.2 \%$ & $92.1 \%$ \\
$2004-2005-2007-2008$ & $29.8 \%$ & $0.3 \%$ & $3.9 \%$ & $64.9 \%$ & $98.9 \%$ \\
\hline
\end{tabular}

Table A3. Average harvest value in rupees per hectare ${ }^{a}$ for rabi (dry season) crops.

\begin{tabular}{ccccc}
\hline & Wheat & Barley & Gram & Mustard \\
\hline $2001-2002-2003-2004$ & 17,659 & 12,730 & 20,155 & 25,180 \\
$2004-2005-2007-2008$ & 21,113 & 14,845 & 20,516 & 26,391 \\
\hline
\end{tabular}

${ }^{\mathrm{a}}(\mathrm{Rs} / \mathrm{qt}) \times(10 \mathrm{qt} / \mathrm{mt}) \times(\mathrm{mt} / \mathrm{ha})$. 
Table A4. Revenue gains in rupees harvest value per hectare ${ }^{a}$ for rabi (dry season) crops.

\begin{tabular}{cccccc}
\hline & \multicolumn{4}{c}{ Average revenues from harvesting } & \multirow{2}{*}{ Average total } \\
\cline { 2 - 5 } & Wheat & Barley & Gram & Mustard & \\
\hline $2001-2002-2003-2004$ & $211,053,266$ & $2,930,340$ & $56,703,270$ & $229,306,216$ & $500,003,092$ \\
$2004-2005-2007-2008$ & $221,227,577$ & $1,817,510$ & $30,577,689$ & $615,747,807$ & $869,370,583$ \\
\hline
\end{tabular}

${ }^{a}$ Harvest in tonnes $\times$ harvest price $(\mathrm{Rs} / \mathrm{qt}) \times(\mathrm{Rs} / \mathrm{qt}) \times(10 \mathrm{qt} / \mathrm{mt})$.

Table A5. Average revenues for kharif (monsoon season) crops in bharatpur district (2002-2003 - 2006-2007).

\begin{tabular}{|c|c|c|c|c|c|}
\hline & \multicolumn{2}{|c|}{ Area planted } & \multirow{2}{*}{ Yield (mt/ha) } & \multirow{2}{*}{ Price (Rs/qt) } & \multirow{2}{*}{ Revenue/ha ${ }^{\mathrm{a}}$} \\
\hline & Hectares & \%age & & & \\
\hline Bajra & 100,406 & $52.4 \%$ & 1.10 & 501 & 5511 \\
\hline Jowar & 48,877 & $25.5 \%$ & 0.56 & 578 & 3237 \\
\hline Rice & 1626 & $0.8 \%$ & 1.58 & 1019 & 16,100 \\
\hline Til & 1611 & $0.8 \%$ & 0.47 & 2650 & 12,455 \\
\hline Cotton & 1036 & $0.5 \%$ & 1.19 & 2183 & 25,978 \\
\hline Sum of 5 & 153,556 & $80.1 \%$ & & & \\
\hline All kharif & 191,596 & & & & \\
\hline \multicolumn{3}{|c|}{ Average weighted by area planted } & & & 5110 \\
\hline
\end{tabular}

${ }^{\mathrm{a}}(\mathrm{Rs} / \mathrm{qt}) \times(10 \mathrm{qt} / \mathrm{mt}) \times(\mathrm{mt} / \mathrm{ha})$.

Table A6. Average revenues for rabi (dry season) crops in bharatpur district (2002-2003 2006-2007).

\begin{tabular}{|c|c|c|c|c|c|}
\hline & \multicolumn{2}{|c|}{ Area planted } & \multirow{2}{*}{ Yield (mt/ha) } & \multirow{2}{*}{ Price (Rs/qt) } & \multirow{2}{*}{ Revenue/ha } \\
\hline & Hectares & \%age & & & \\
\hline Mustard & 214,913 & $58.2 \%$ & 1.27 & 1661 & 21,095 \\
\hline Wheat & 132,827 & $36.0 \%$ & 3.32 & 717 & 23,804 \\
\hline Gram & 8516 & $2.3 \%$ & 1.24 & 1767 & 21,911 \\
\hline Barley & 3692 & $1.0 \%$ & 2.76 & 581 & 16,036 \\
\hline Potato & 1225 & $0.3 \%$ & 11.95 & 469 & 56,046 \\
\hline Sum of 5 & 361,173 & $97.8 \%$ & & & \\
\hline All Rabi & 369,206 & & & & \\
\hline
\end{tabular}

Average weighted by area planted

${ }^{\mathrm{a}}(\mathrm{Rs} / \mathrm{qt}) \times(10 \mathrm{qt} / \mathrm{mt}) \times(\mathrm{mt} / \mathrm{ha})$.

Table A7. Calculation of gain from farming satellite wetlands.

\begin{tabular}{cc}
\hline Hectares of wetlands & 4250 \\
Area drained under status quo & $50 \%$ \\
Rabi hectares farmed & 2125 \\
Value of rabi crops per hectare ${ }^{\mathrm{a}}$ & $\$ 444$ \\
Value of rabi crops & $\$ 942,535$ \\
Kharif hectares farmed & 1063 \\
Value of kharif crops per hectare & $\$ 102$ \\
Value of kharif crops & $\$ 108,591$ \\
Value of all crops & $\$ 1,051,127$ \\
\hline
\end{tabular}

${ }^{\mathrm{a}}$ Exchange rate of $\$ 1=$ Rs. 50. 
information in the tables represent averages over the five year period of 2002-2003 through 2006-2007. These district-level data include the area planted, the crop output, and the harvest prices of bajra, jowar, wheat, gram, and barley. The prices of rice, til, cotton, mustard, and potato are from the Central government [74]-[77]. Six of the fourteen satellite wetlands identified by Mathur et al. [52] comprising $42.5 \mathrm{~km}^{2}$ appear to be on potential agricultural lands rather than being reservoirs or canals.

Submit or recommend next manuscript to SCIRP and we will provide best service for you:

Accepting pre-submission inquiries through Email, Facebook, LinkedIn, Twitter, etc. A wide selection of journals (inclusive of 9 subjects, more than 200 journals)

Providing 24-hour high-quality service

User-friendly online submission system

Fair and swift peer-review system

Efficient typesetting and proofreading procedure

Display of the result of downloads and visits, as well as the number of cited articles Maximum dissemination of your research work

Submit your manuscript at: http://papersubmission.scirp.org/

Or contact me@scirp.org 